\title{
FAKTOR-FAKTOR YANG BERHUBUNGAN DENGAN KEJADIAN ASCARIASIS PADA MURID SEKOLAH DASAR
}

\author{
Atikah Mardhika Ihsan ${ }^{1}$, Selfi Renita Rusjdi², Siti Nurhajjah³
}

\begin{abstract}
Abstrak
Kejadian Ascariasis masih tinggi di Kota Padang, terutama pada anak usia sekolah dasar. Banyak faktor yang mempengaruhi tingginya kejadian Ascariasis ini. Tujuan penelitian ini adalah untuk mengetahui faktor-faktor yang berhubungan dengan kejadian Ascariasis pada murid Sekolah Dasar. Penelitian ini merupakan penelitian analitik dengan metode cross sectional study yang dilakukan pada 122 murid SDN 25 dan 28 Purus, Kota Padang pada bulan Desember 2013. Faktor-faktor yang diteliti antara lain higienitas perorangan, tingkat pengetahuan ibu, sanitasi lingkungan, tempat tinggal, dan tingkat penghasilan orang tua. Hubungan antar variabel dianalisis dengan uji chi-square. Hasil penelitian menunjukkan bahwa murid yang positif Ascariasis sebesar 34,4\%. Kejadian Ascariasis ditemukan pada murid yang higienitas perorangan kurang baik sebesar $52 \%$, tingkat pengetahuan ibu yang rendah sebesar $34,9 \%$, sanitasi lingkungan yang kurang baik sebesar $29,3 \%$, dan tingkat penghasilan orang tua yang rendah sebesar $37 \%$. Analisis statistik menunjukkan tidak terdapat hubungan bermakna antara higienitas perorangan $(p=0.06)$, pengetahuan ibu $(p=1)$, sanitasi lingkungan $(p=0,35)$, dan tingkat penghasilan orang tua $(p=0,59)$ dengan kejadian Ascariasis. Kesimpulan: Kejadian Ascariasis pada pada murid SDN 25 dan 28 Purus, Kota Padang tahun 2013 tidak berkaitan dengan higienitas perorangan, pengetahuan ibu, sanitasi lingkungan, dan tingkat penghasilan orang tua.

Kata kunci: Ascariasis, higienitas perorangan, sanitasi, pengetahuan ibu, penghasilan
\end{abstract}

\begin{abstract}
The prevalence of Ascariasis is still high in Padang, especially at primary school age children. There are many factors contribute to the high incidence of this Ascariasis. The purpose of this study was to know the factors that associated with the incidence of Ascariasis in primary school. This study uses an analytical design method of cross -sectional study on 122 students in 25 and 28 primary school Purus, Padang in December 2013. The factors studied include personal hygiene, level of maternal knowledge, sanitary living environment, and the level of parental income. The relationship between all variables was analyzed by Chi-Square test. The results showed that students were positive Ascariasis was 34.4\%. Ascariasis incidence in poor individual hygiene students was 52\%, a low level of maternal knowledge was 34,9\%, poor environmental sanitation was $29,3 \%$, and a low level of parental income was $37 \%$. Statistical analysis showed there was not significant relationship between the individual hygiene $(p=0.06)$, the level of maternal knowledge $(p=1)$, environmental sanitation $(p=0,35)$, and the parental income $(p=0,59)$ with Ascariasis. Conclusion: Ascariasis incidence in 25 and 28 primary school Purus, Padang in 2013 was not associated with individual hygiene, the level of maternal knowledge, environmental sanitation, and the parental income.
\end{abstract}

Keywords: Ascariasis, individual hygiene, maternal knowledge, sanitation, income

Afiliasi Penulis : 1. Fakultas Kedokteran Universitas Andalas, 2. Bagian Parasitologi Fakultas Kedokteran Universitas Andalas, 3. Bagian Anatomi Fakultas Kedokteran Universitas Andalas. Korespondensi: Atikah Mardhika Ihsan, email: atikahm1708@gmail.com,telp: 081270252652 


\section{PENDAHULUAN}

Indonesia merupakan negara berkembang dengan angka kejadian penyakit infeksi yang tinggi. Penyakit infeksi bisa disebabkan oleh bakteri, virus, parasit, serta jamur. ${ }^{1}$ Salah satu penyakit infeksi yang masih tinggi angka kejadiannya di Indonesia yaitu kecacingan. Penyakit kecacingan ini masih merupakan masalah kesehatan yang utama pada masyarakat. ${ }^{2}$

Berdasarkan data World Health Organization (WHO) pada tahun 2008 didapatkan sekitar 800 juta sampai dengan 1 milyar penduduk di dunia terinfeksi cacing Ascaris lumbricoides, 700 juta sampai 900 juta penduduk dunia terinfeksi cacing tambang (Necator americanus dan Ancylostoma duodenale), 500 juta penduduk terinfeksi Trichuris trichiura, dan 300 juta penduduk dunia terinfeksi Oxyuris vermicularis. Data WHO (2013) pada bulan Juni, didapatkan lebih dari 1,5 milyar atau $24 \%$ dari populasi penduduk di dunia terinfeksi Soil Transmitted Helminths. ${ }^{3}$

Soil Transmitted Helminths (STH) merupakan golongan cacing usus yang ditularkan melalui tanah dan membutuhkan tanah sebagai media perkembangbiakannya dengan didukung oleh kondisi tertentu. Kondisi yang dapat mendukung perkembangbiakan cacing tersebut tergantung dari jenis cacing itu sendiri. Cacing yang masuk dalam golongan STH yakni Ascaris lumbricoides, Necator americanus, Ancylostoma duodenale, Trichuris trichiura, dan Strongyloides stercoralis. ${ }^{1,4}$

Infeksi cacing $A$. lumbricoides merupakan kejadian terbanyak yang ditemukan di dunia yaitu dengan prevalensi sekitar 807 juta jiwa. Angka kejadian Ascariasis banyak ditemukan di negara berkembang dengan lingkungan yang buruk serta di daerah tropis seperti Indonesia. ${ }^{1,4}$ Angka prevalensi tertinggi tetap didapatkan pada golongan anak usia sekolah dasar (5-9 tahun) karena ada hubungannya dengan kebiasaan anak-anak yang sering bermain di tanah yang terkontaminasi cacing sehingga lebih mudah terinfeksi. ${ }^{2,5}$

Angka kejadian Ascariasis ini terutama disebabkan karena banyaknya telur disertai dengan daya tahan telur cacing pada keadaan tanah kondusif. Parasit ini lebih banyak ditemukan pada tanah liat dengan kelembaban tinggi dan suhu $25^{\circ}-30^{\circ} \mathrm{C}$ sehingga sangat baik untuk menunjang perkembangan telur cacing tersebut. ${ }^{1,6,7}$ Seseorang akan terinfeksi $A$. lumbricoides apabila tertelan telur $A$. lumbricoides yang infektif bersamaan dengan makanan atau minuman yang terkontaminasi. ${ }^{1}$

Gejala klinis yang ditimbulkan Ascariasis dapat terjadi akibat migrasi larva $A$. Lumbricoides seperti perdarahan kecil di dinding alveolus, batuk dan demam. Sedangkan gejala akibat cacing dewasa berasal dari dalam usus atau migrasi ke dalam lumen usus yang lain atau perforasi ke dalam peritoneum seperti cholesistitis, apendisitis, dan gangguan gizi akibat malabsorpsi pada anak. $^{4}$

Cara menegakkan diagnosis Ascariasis biasanya melalui pemeriksaan laboratorium dengan ditemukannya telur A. lumbricoides di dalam tinja seseorang, ditemukannya larva $A$. lumbricoides di dalam sputum seseorang, atau cacing dewasa keluar melalui anus ataupun bersama dengan muntahan. .,8,9 $^{4}$ 
Faktor-faktor yang berhubungan dengan Ascariasis diantaranya lingkungan yang mendukung, kebersihan lingkungan yang rendah, perilaku hidup bersih dan sehat (PHBS) yang rendah, pengetahuan yang kurang, tingkat penghasilan orang tua yang rendah, dan pendidikan yang rendah. ${ }^{5}$ Keadaan lingkungan yang mendukung untuk perkembangan telur A.lumbricoides menjadi bentuk infektif diantaranya adalah iklim yang tropis, tanah yang subur, tanah yang lembab, dan sinar matahari yang memadai. ${ }^{1,6}$ Berdasarkan penelitian $\mathrm{Pe}$ brisa (2008) di SDN 30 Air Dingin Kec. Koto Tangah Padang menyatakan bahwa adanya hubungan bermakna antara penyakit kecacingan dengan higienitas perorangan, tingkat pengetahuan orang tua, dan sanitasi lingkungan tempat tinggalnya. ${ }^{10}$

Tingkat pengetahuan orang tua khususnya ibu, yang kurang mengenai kesehatan akan berdampak pada kurangnya edukasi kesehatan yang didapat anak di rumah. Edukasi kesehatan yang kurang dapat menyebabkan anak memiliki perilaku atau kebiasaan yang tidak mengikuti standar kesehatan, sehingga anak mudah untuk terserang penyakit. ${ }^{9}$ Selain itu, hiegene perorangan yang dapat mempengaruhi kejadian Ascariasis meliputi kebiasaan buang air besar tidak menggunakan jamban, kebiasaan tidak menggunakan alas kaki waktu bermain diluar rumah bahkan di sekolah, kebiasaan tidak rutin memotong kuku tangan dan kaki, kebiasaan tidak mencuci tangan dengan sabun sebelum makan dan keluar kamar mandi, kebiasaan tidak mencuci buah-buahan, dan sayur-sayuran sebelum dimakan, serta kebiasaan bermain tanah yang tercemar oleh tinja. ${ }^{11}$ Kejadian Ascariasis ditemukan tinggi jumlahnya pada daerah dengan sanitasi lingkungan yang buruk dan daerah dimana feses manusia dijadikan pupuk untuk sayur-mayur ataupun buahbuahan. ${ }^{11}$ Kejadian Ascariasis juga banyak ditemukan di negara berkembang dengan penduduk di negara tersebut sebagian besar berpenghasilan rendah. Keluarga miskin mengalami keterbatasan dalam hal pemenuhan gizi mereka setiap harinya sehingga cenderung mudah terserang Ascariasis. ${ }^{4}$

\section{METODE}

Penelitian yang dilakukan bersifat cross sectional study pada Mei 2013 sampai Januari 2014. Lokasi penelitian di SDN 25 dan SDN 28 Purus Kota Padang sedangkan pemeriksaan telur A.lumbricoides dilakukan di Laboratorium Parasitologi Fakultas Kedokteran Universitas Andalas. Sampel penelitian adalah murid SDN 25 dan 28 Purus, Padang yang berjumlah 122 orang. Data mengenai higienitas perorangan, tingkat pengetahuan ibu dan penghasilan orang tua didapat melalui kuesioner, sedangkan data mengenai sanitasi lingkungan didapat dengan observasi lingkungan disekitar rumah responden. Untuk menemukan telur A. lumbricoides dilakukan pemeriksaan feses langsung dengan menggunakan pewarna eosin. Data yang diperoleh dikumpulkan dan diolah dengan menggunakan metode chi-square test.

\section{HASIL DAN PEMBAHASAN}

Karakteristik responden digambarkan oleh tabel 1. Hasil penelitian 
yang didapatkan adalah responden lebih banyak berjenis kelamin laki-laki dibandingkan perempuan. Usia yang terbanyak sebagai responden adalah murid dengan usia 7 tahun sebanyak 23 orang. Jumlah murid kelas I lebih banyak dari jumlah murid kelas lain, yaitu sebanyak 25 orang diikuti dengan jumlah murid kelas IV dan kelas III.

Tabel 1. Karakteristik sampel penelitian

\begin{tabular}{|c|c|c|c|}
\hline & & $f$ & $\%$ \\
\hline Jenis & Kelamin & & \\
\hline - & Laki-laki & 63 & 51,6 \\
\hline & Perempuan & 59 & 48,4 \\
\hline Usia & & & \\
\hline - & 6 tahun & 5 & 4,1 \\
\hline - & 7 tahun & 23 & 18,9 \\
\hline - & 8 tahun & 19 & 15,6 \\
\hline - & 9 tahun & 21 & 17,2 \\
\hline - & 10 tahun & 21 & 17,2 \\
\hline - & 11 tahun & 20 & 16,4 \\
\hline - & 12 tahun & 9 & 7,4 \\
\hline - & 13 tahun & 3 & 2,5 \\
\hline - & 14 tahun & 1 & 0,8 \\
\hline Kelas & & & \\
\hline - & I & 25 & 20,5 \\
\hline - & II & 16 & 13,1 \\
\hline - & III & 20 & 16,4 \\
\hline - & IV & 21 & 17,2 \\
\hline - & V & 23 & 18,9 \\
\hline - & VI & 17 & 13,9 \\
\hline Pend & ikan Orangtu & & \\
\hline - & SD & 47 & 38,5 \\
\hline - & SMP & 44 & 36,1 \\
\hline - & SMA & 27 & 22,1 \\
\hline - & Sarjana & 4 & 3,3 \\
\hline Peke & aan Orangtua & & \\
\hline - & Buruh & 70 & 57,4 \\
\hline - & Nelayan & 18 & 14,8 \\
\hline - & Pedagang & 25 & 20,5 \\
\hline - & $\begin{array}{l}\text { Pegawai } \\
\text { swasta }\end{array}$ & 8 & 6,6 \\
\hline - & PNS & 1 & 0,8 \\
\hline
\end{tabular}

Dari hasil penelitian mengenai karakteristik sampel penelitian juga didapat bahwa orang tua dari murid SDN 25 dan 28 Purus, Kota Padang lebih banyak yang memiliki pendidikan terakhir SD. Pekerjaan dari orangt tua murid SDN 25 dan 28 Purus yang terbanyak adalah sebagai buruh sebanyak 70 orang.

Berdasarkan penelitian yang telah dilakukan diperoleh hasil mengenai distribusi frekuensi kejadian Ascariasis, higienitas perorangan, tingkat pengetahuan ibu, sanitasi lingkungan tempat tinggal, dan tingkat penghasilan orangtua pada murid SDN 25 dan 28 Purus, Kota Padang tahun 2013 seperti terlihat pada tabel 2. Pada penelitian ini didapatkan bahwa murid SDN 25 dan 28 Purus yang menderita Ascariasis berjumlah 42 orang (34,4\%). Penelitian terhadap tingkat pengetahuan ibu didapat bahwa 63 orang $(51,6 \%)$ memiliki tingkat pengetahuan yang rendah mengenai infeksi kecacingan khususnya Ascariasis.

Kejadian Ascariasis yang didapat pada penelitian ini lebih rendah dibandingkan penelitian yang dilakukan oleh Gusta pada murid SD $19 \mathrm{Kp}$. Manggis, kota Padang Panjang yaitu sebesar $59.8 \% .^{12}$ Rendahnya angka kejadian Ascariasis menandakan bahwa terjadi penurunan faktor risiko yang menyebabkan berkurangnya rantai penularan dari infeksi A.lumbricoides. ${ }^{13}$ Faktor risiko yang dimaksud seperti higienitas perorangan masyarakat yang membaik, tingkat pengetahuan yang tinggi, sanitasi lingkungan yang membaik, tingkat penghasilan yang tinggi, dan status gizi yang baik. ${ }^{11}$ Penurunan kejadian Ascariasis pada murid SDN 25 dan 28 Purus Kota Padang mungkin saja terjadi karena banyak hal, seperti higienitas perorangan masyarakat Purus dan status gizi anak- 
anak disana yang membaik. Namun penilaian status gizi tidak dilakukan pada penelitian ini.

Tabel 2. Kejadian Ascariasis, Pengetahuan Ibu, Higienitas, Sanitasi, dan Tingkat Penghasilan

\begin{tabular}{|c|c|c|}
\hline & $\mathbf{F}$ & $\%$ \\
\hline \multicolumn{3}{|l|}{ Kejadian Ascariasis } \\
\hline - Positif & 42 & 34,4 \\
\hline - Negatif & 80 & 65,6 \\
\hline \multicolumn{3}{|c|}{ Tingkat Pengetahuan Ibu } \\
\hline - Rendah & 63 & 51.6 \\
\hline Tinggi & 59 & 48,4 \\
\hline \multicolumn{3}{|l|}{ Higienitas Perorangan } \\
\hline Kurang baik & 25 & 20,5 \\
\hline Baik & 97 & 79.5 \\
\hline \multicolumn{3}{|l|}{ Sanitasi Lingkungan } \\
\hline Kurang Baik & 58 & 47,5 \\
\hline Baik & 64 & 52,5 \\
\hline \multicolumn{3}{|l|}{$\begin{array}{l}\text { Tingkat Penghasilan } \\
\text { Orangtua }\end{array}$} \\
\hline - Rendah & 73 & 59,8 \\
\hline - $\quad$ Tinggi & 49 & 40,2 \\
\hline
\end{tabular}

Keterangan: $f=$ frekuensi, $\%=$ persentase .

Tabel 2 menjelaskan juga bahwa lebih banyak murid-murid yang memiliki higienitas perorangan baik yaitu berjumlah 97 orang (79,5\%). Sanitasi lingkungan pada murid SDN 25 dan 28 Purus, Kota Padang terlihat bahwa hampir separuh responden (47,5\%) memiliki sanitasi lingkungan yang kurang baik. Penelitian ini, mendapatkan hasil bahwa lebih banyak orangtua murid yang berpenghasilan rendah $(59,8 \%)$.

Tabel 3 memperlihatkan mengenai hubungan tingkat pengetahuan ibu dengan kejadian Ascariasis. Penelitian ini mendapatkan bahwa murid yang memiliki ibu dengan tingkat pengetahuan tentang Ascariasisnya rendah dan mengalami Ascariasis berjumlah 22 orang $(34,9 \%)$, sedangkan ibu dengan pengetahuan yang rendah dan memiliki anak yang tidak terinfeksi Ascariasis berjumlah 41 orang $(65,1 \%)$. Hasil uji statistik antara tingkat pengetahuan ibu dengan kejadian Ascariasis pada murid SDN 25 dan 28 Purus, Kota Padang tahun 2013 yang menjadi responden diperoleh hasil $p$ value 1,00 ( $p>0,05)$, dengan demikian tidak terdapat hubungan yang bermakna antara tingkat pengetahuan ibu dengan kejadian Ascariasis pada murid SDN 25 dan 28 Purus, Kota Padang tahun 2013.

\section{Tabel 3. Hubungan pengetahuan ibu dengan kejadian Ascariasis Kejadian

\begin{tabular}{|c|c|c|c|}
\hline \multirow{2}{*}{$\begin{array}{l}\text { Penge- } \\
\text { tahuan }\end{array}$} & \multicolumn{2}{|c|}{$\begin{array}{l}\text { Kejadian } \\
\text { Ascariasis }\end{array}$} & \multirow{2}{*}{ Total } \\
\hline & Positif & Negatif & \\
\hline
\end{tabular} \\ $\begin{array}{lllllll}\text { Rendah } & 22 & 34,9 & 41 & 65,1 & 63 & 100\end{array}$

$\begin{array}{llllllll}\text { Tinggi } & 20 & 33,9 & 39 & 66,1 & 59 & 100 & 1,00\end{array}$

$\begin{array}{lllllll}\text { Total } \quad 42 & 34,4 & 80 & 65,6 & 122 & 100\end{array}$ \\ Keterangan: $\mathrm{f}=$ frekuensi, $\%=$ persentase, $\mathrm{N}=$ jumlah, $p=$ nilai $p$.}

Hasil penelitian ini berbeda dengan hasil penelitian Hasan (2012) yang menemukan bahwa terdapat hubungan yang bermakna antara kedua variabel yaitu makin tinggi pengetahuan ibu dari murid maka makin rendah prevalensi Ascariasis yang ditemukan. ${ }^{14}$

Peran ibu dalam menjaga kesehatan anak sangatlah dominan, karena sebagian besar ibu yang merawat, membesarkan, serta membantu mendidik anak didalam kehidupan sehari-harinya. Tingkat pengetahuan ibu yang kurang mengenai kesehatan akan berdampak pada kurangnya edukasi kesehatan yang seorang anak dapatkan dirumah. Edukasi kesehatan yang kurang akan mempengaruhi perilaku dan kebiasaan seorang anak dalam berperilaku hidup bersih dan sehat. ${ }^{11}$ 
Tingginya jumlah anak yang tidak terinfeksi namun memiliki ibu yang pengetahuannya rendah mungkin disebabkan karena kejadian Ascariasis dapat dipengaruhi oleh multifaktorial, seperti kesadaran orang tua yang tinggi terhadap kebersihan sehingga mereka mendidik lebih baik tentang kebersihan walaupun orang tua murid tersebut tidak memiliki pengetahuan tentang Ascariasis.

Tabel 4. Hubungan higienitas perorangan dengan kejadian Ascariasis

\begin{tabular}{|c|c|c|c|c|c|c|c|}
\hline \multirow{3}{*}{$\begin{array}{c}\text { Higienitas } \\
\text { perorang } \\
\text { an }\end{array}$} & \multicolumn{4}{|c|}{$\begin{array}{c}\text { Kejadian } \\
\text { Ascariasis }\end{array}$} & \multirow{2}{*}{\multicolumn{2}{|c|}{ Total }} & \multirow[t]{3}{*}{$p$} \\
\hline & \multicolumn{2}{|c|}{ Positif } & \multicolumn{2}{|c|}{ Negatif } & & & \\
\hline & $\mathrm{F}$ & $\%$ & $f$ & $\%$ & $\mathrm{~N}$ & $\%$ & \\
\hline $\begin{array}{l}\text { Kurang } \\
\text { baik }\end{array}$ & 13 & 52 & 12 & 48 & 25 & 100 & 0,06 \\
\hline Baik & 29 & 29,9 & 68 & 70,1 & 97 & 100 & \\
\hline Total & 42 & 34,4 & 80 & 65,6 & 122 & 100 & \\
\hline
\end{tabular}

Keterangan: $f=$ frekuensi, $\%=$ persentase, $\mathrm{N}=$ jumlah, $p=$ nilai $p$.

Tabel 4 menjelaskan mengenai hubungan higienitas perorangan dengan kejadian Ascariasis pada murid SDN 25 dan 28 Purus, Kota Padang tahun 2013. Hasil penelitian yang didapat adalah murid yang memiliki higienitas perorangan kurang baik dan mengalami Ascariasis berjumlah 13 orang (52\%), sedangkan murid dengan higienitas perorangan kurang baik dan tidak menderita Ascariasis berjumlah 12 orang (48\%). Hasil uji statistik antara higienitas perorangan dengan kejadian Ascariasis pada murid SDN 25 dan 28 Purus, Kota Padang tahun 2013 diperoleh hasil $p$ value 0,06 ( $p>0,05)$, dengan demikian tidak terdapat hubungan yang bermakna antara higienitas perorangan dengan kejadian Ascariasis pada murid SDN 25 dan 28 Purus, Kota Padang tahun 2013.

Hal ini sama dengan penelitian Ariska (2011) di Jambi yang juga mendapatkan hasil bahwa jumlah murid yang memiliki higienitas perorangan kurang baik dengan negatif Ascariasis lebih tinggi dibandingkan dengan murid yang memiliki higienitas perorangan yang kurang baik dan menderita Ascariasis. ${ }^{15}$

Higienitas perorangan yang tidak baik yang dinilai adalah tidak menggunakan alas kaki saat bermain keluar rumah maupun saat bermain di sekolah pada jam istirahat, tidak rutin memotong kuku $1 \mathrm{x}$ dalam seminggu, jarang mencuci tangan dengan sabun sebelum makan ataupun setelah keluar dari WC/ jamban, dan tidak biasa mencuci buah ataupun sayuran dengan air mengalir sebelum dikonsumsi. Kebiasaan tidak menggunakan alas kaki keluar rumah termasuk saat bermain di tanah merupakan faktor penyebaran telur A.lumbricoides secara tidak langsung. Telur yang terbawa pada sela-sela jari kaki akan terbawa ke dalam rumah dan nantinya akan mudah terhirup dan termakan oleh anak tersebut. ${ }^{10}$

Tidak adanya hubungan antara higienitas perorang dengan kejadian Ascariasis pada murid SDN 25 dan 28 Purus, Kota Padang mungkin saja terjadi karena terdapat faktor lain yang tidak diteliti dalam penelitian ini yang mempengaruhi kejadian Ascariasis. Faktor yang mempengaruhi Ascariasis selain dari faktor eksternal, terdapat faktor internal yaitu status gizi anak tersebut. Walaupun banyak faktor yang mendukung seseorang terinfeksi A.lumbricoides jika orang tersebut memiliki status gizi yang 
baik, tidak akan terjadi penularan dari Ascariasis karena terputusnya rantai penularan saat telur masuk kedalam tubuh anak melalui sistem imun yang baik. ${ }^{16-18}$

Tabel 5. Hubungan sanitasi lingkungan dengan kejadian Ascariasis.

\begin{tabular}{|c|c|c|c|c|c|c|c|}
\hline \multirow{3}{*}{$\begin{array}{c}\text { Sanitasi } \\
\text { lingkungan }\end{array}$} & \multicolumn{4}{|c|}{ Kejadian Ascariasis } & \multirow{2}{*}{\multicolumn{2}{|c|}{ Total }} & \multirow{3}{*}{$p$} \\
\hline & \multicolumn{2}{|c|}{ Positif } & \multicolumn{2}{|c|}{ Negatif } & & & \\
\hline & $f$ & $\%$ & $f$ & $\%$ & $\mathrm{~N}$ & $\%$ & \\
\hline $\begin{array}{c}\text { Kurang } \\
\text { baik }\end{array}$ & 17 & 29,3 & 41 & 70,7 & 58 & 100 & \\
\hline Baik & 25 & 39,1 & 39 & 60,9 & 64 & 100 & 0,35 \\
\hline Total & 42 & 34,4 & 80 & 65,6 & 122 & 100 & \\
\hline
\end{tabular}

Keterangan: $f=$ frekuensi, $\%=$ persentase, $\mathrm{N}=$ jumlah, $p=$ nilai $p$.

Tabel 5 memperlihatkan mengenai hubungan sanitasi lingkungan dengan kejadian Ascariasis pada murid SDN 25 dan 28 Purus, Kota Padang tahun 2013. Hasil penelitian pada tabel 5 menjelaskan bahwa murid yang sanitasi lingkungan rumahnya kurang baik dan mengalami Ascariasis lebih rendah nilainya $(29,3 \%)$ dibandingkan dengan sanitasi lingkungan rumah kurang baik dan tidak menderita Ascariasis (70,7\%). Hasil uji statistik antara sanitasi lingkungan dengan kejadian Ascariasis pada murid SDN 25 dan 28 Purus, Kota Padang tahun 2013 yang menjadi responden diperoleh hasil $p$ value 0,347 ( $p>0,05)$, dengan demikian tidak terdapat hubungan yang bermakna antara sanitasi lingkungan dengan kejadian Ascariasis pada murid SDN 25 dan 28 Purus, Kota Padang tahun 2013.

Hasil yang didapat ini berbeda dengan penelitian Ariska (2011) di Kota Jambi yang menyatakan terdapat hubungan antara kedua variabel tersebut. ${ }^{15}$ $\mathrm{Hal}$ ini mungkin disebabkan karena terdapat faktor lain yang mempengaruhi kejadian Ascariasis pada SDN 25 dan 28 Purus, Padang faktor internal seperti status gizi yang dapat mempengaruhi seorang anak terinfeksi A.lumbricoides. ${ }^{16}$

Tabel 6. Hubungan tingkat penghasilan orang tua murid dengan kejadian Ascariasis

\begin{tabular}{cccccccc}
\hline \multirow{2}{*}{$\begin{array}{c}\text { Tingkat } \\
\text { Pengha- } \\
\text { silan }\end{array}$} & \multicolumn{4}{c}{$\begin{array}{c}\text { Kejadian } \\
\text { Ascariasis }\end{array}$} & Total & \\
\cline { 2 - 6 } & Positif & Negatif & & & $\boldsymbol{p}$ \\
\cline { 2 - 6 } & $\mathrm{F}$ & $\%$ & $\mathrm{~F}$ & $\%$ & $\mathrm{~N}$ & $\%$ & \\
\hline Rendah & 27 & 37 & 46 & 63,0 & 73 & 100 & \\
Tinggi & 15 & 30,6 & 34 & 69,4 & 49 & 100 & 0,59 \\
Total & 42 & 34,4 & 80 & 65,6 & 122 & 100 & \\
\hline
\end{tabular}

Keterangan: $f=$ frekuensi, $\%=$ persentase, $\mathrm{N}=$ jumlah, $p=$ nilai $p$.

Hasil penelitian mengenai hubungan tingkat penghasilan orang tua murid dengan kejadian Ascariasis telihat pada tabel 6 . Murid yang memiliki orang tua dengan tingkat penghasilan rendah dan mengalami Ascariasis berjumlah 27 orang $(36,9 \%)$, lebih sedikit dibandingkan dengan yang tidak mengalami Ascariasis yang berjumlah 46 orang (63\%). Hasil uji statistik antara tingkat penghasilan orangtua murid dengan kejadian Ascariasis pada murid SDN 25 dan 28 Purus, Kota Padang tahun 2013 diperoleh $p$ value 0,595 ( $p>0,05)$, dengan demikian tidak terdapat hubungan yang bermakna antara tingkat penghasilan orang tua murid dengan kejadian Ascariasis pada murid SDN 25 dan 28 Purus, Kota Padang tahun 2013.

Hasil penelitian ini sama dengan hasil penelitian oleh Djafar (2008) yaitu tidak ada hubungan antara kejadian Ascariasis dengan tingkat penghasilan orang tua murid. Lain halnya dengan 
hasil penelitian Pebrisa (2008) pada murid di Koto Tangah, Padang dan Ginting (2003) di Medan dimana terdapat hubungan antara kejadian Ascariasis dengan tingkat penghasilan keluarga. ${ }^{10,19}$

Tingkat penghasilan orang tua yang tidak berhubungan dengan kejadian Ascariasis pada murid SDN 25 dan 28 Purus, Kota Padang tahun 2013 bisa saja terjadi, karena walaupun penghasilan orang tua murid yang rendah mereka masih dapat memenuhi gizi anak-anak mereka. Hasil penelitian mengenai karakteristik responden murid SDN 25 dan 28 Purus didapatkan bahwa sebagian besar pekerjaan orang tua murid adalah buruh diikuti dengan pedagang, dan nelayan.

\section{DAFTAR RUJUKAN}

1. Sutanto I, Ismid IS, Sjarifuddin PK, Sungkar S. Buku Ajar Parasitologi Kedokteran. Jakarta: FKUI; 2008.

2. Hotez PJ, Molyneux DH, Fenwick A, Kumaresan J, Sachs SE, Sachs JD, et al. Control of Neglected Tropical Diseases. N Engl J Med. 2007;357-(10):1018- 27.

3. WHO. Soil Transmitted Helminth. Available at: http://www.who.int/intestinal worms/en/ (cited Mei 2013).

4. Rampengan TH. Penyakit Infeksi Tropik pada Anak. Ed 2, Jakarta: EGC; 2005. 23843.

5. Manganelli L, Berrilli F, DiCave D, Ercoli L, Gioia C, Otranto D, et al. Intestinal Parasite Infections in Immigrant Children in the City of Rome, Related Risk Factors and Possible Impact on Nutritional Status. Parasit Vectors. 2011;5(265) :1-5.

6. Duc PP, Viet HN, Hattendorf J, Zins-stag J, Dac CP, Zurbrugg $C$, et al. Ascaris lumbricoides and Trichuris trichiura Infection Associated with Wastewater and Human Excreta Use in Agriculture in Vietnam. Parasitol Int. 2013;62:172- 80.

\section{SIMPULAN}

Sepertiga murid SDN 25 dan 28 Purus Kota Padang tahun 2013 mengalami Ascariasis. Sebagian besar murid memiliki higienitas perorangan yang baik. Lebih dari separuh jumlah murid memiliki ibu dengan tingkat pengetahuan yang rendah, tempat tinggal dengan sanitasi lingkungan baik, dan berpenghasilan yang rendah. Tidak ada hubungan antara pengetahuan ibu, higienitas perorangan anak, sanitasi lingkungan, dan tingkat penghasilan orang tua dengan kejadian Ascariasis pada murid SD 25 dan 28 Purus, Kota Padang tahun 2013.

7. Widjana DP, Sutisna P. Prevalence of SoilTransmitted Helminth Infections in the Rural Population of Bali, Indonesia. Southeast Asian J Trop Med Public Health. 2000;31(3):454-9.

8. Natadisastra D, Ridad A. Parasitolo-gi Kedokteran. Jakarta: EGC; 2009.

9. Gillespie SH, Pearson RD. Principles and Practice of Clinical Parasitology. England: John Wiley \& Sons; 2001. 515- 522.

10. Pebrisa D. Faktor-Faktor yang Berhubungan dengan Kejadian Kecacingan pada Murid SDN 30 Air Dingin Kecamatan Koto Tangah Kota Padang Tahun 2008. Skripsi. Padang: Program S1 Sarjana Kesehatan Masyarakat Universitas Andalas; 2008.

11. Bieri FA, Gray DJ, Williams GM, Raso G, Li YS, Yuan L, et al. Health Education Package to Prevent Worm Infections in Chinese School Children. N Engl J Med. 2013; 368(17) :1603-12.

12. Gusta F. Hubungan antara infeksi cacing Ascaris lumbricoides dengan prestasi belajar di SDN 19 Kampung Manggis Kota Padang Panjang. Skripsi. Padang: Progran S1 Sarjana Kesehatan Masyarakat Universitas Andalas; 2008. 
13. Schimidlin T, Hurlimann E, Silue KD, Yapi RB, Houngbedji C, Kouadio BA, et al. Effects of Hygiene and Defecation Behavior on Helminth and Intestinal Protozo Infections in Taabo, Core d'lvoire. PLos ONE. 2013;8(6):1- 12.

14. Hasan D. Faktor-Faktor yang Berhu-bungan dengan Kejadian Ascariasis pada Murid SDN 192/IV Kelurahan Talang Banjar Kota Jambi Tahun 2012. Skripsi. Padang: Program S1 Sarjana Kedokteran Universitas An-dalas; 2012.

15. Ariska BM. Beberapa faktor yang berhubungan dengan kejadian infeksi cacing Ascaris lumbricoides pada murid SDN IV Sipin Kota Jambi. Skripsi. Padang: Program S1 Sarjana Kedokteran Universitas Andalas; 2012.
16. Krevani CK. Hubungan Infeksi Ascaris lumbricoides dengan Status Gizi Murid Kelas I dan II SDN 23 Pasir Sebelah Kecamatan Koto Tangah Kota Padang. Skripsi. Padang: Program S1 Sarjana Kedokteran Universitas Andalas; 2012.

17. Markell EK, Voge M, John DT. Medical Parasitology. $7^{\text {th }} \mathrm{Ed}$, Philadelphia: WB Saunders Company; 1992. 261-8.

18. Brown HW, Neva FA.Basic Clinical Parasitology. $6^{\text {th }}$ Ed. Connecticut: Appleton \& Lange; 1994.139- 44.

19. Ginting A. Faktor-faktor yang Berhubungan dengan kejadian kecacingan pada anak sekolah dasar di desa tertinggal kecamatan Poungururan Kabupaten Samosir. Skripsi. Medan: Program S1 Sarjana Kedokteran Universitas Sumatera Utara; 2008. 